\title{
Lipids as a proxy for larval starvation and feeding condition in small pelagic fish: a field approach on match-mismatch effects on Baltic sprat
}

\author{
Janna Peters ${ }^{1,2, *}$, Rabea Diekmann ${ }^{1,3}$, Catriona Clemmesen ${ }^{4}$, Wilhelm Hagen ${ }^{2}$ \\ ${ }^{1}$ Center of Marine and Climate Research, Institute of Hydrobiology and Fisheries Science, University of Hamburg, \\ Grosse Elbstrasse 133, 22767 Hamburg, Germany \\ ${ }^{2}$ Marine Zoology, BreMarE - Bremen Marine Ecology, University of Bremen, PO Box 330440, 28334 Bremen, Germany \\ ${ }^{3}$ Thünen Institute for Fisheries Ecology, Palmaille 9, 22767 Hamburg, Germany \\ ${ }^{4}$ Helmholtz Centre for Ocean Research (GEOMAR), Düsternbrooker Weg 20, 24105 Kiel, Germany
}

\begin{abstract}
Sprat Sprattus sprattus larvae were used as model organisms to evaluate whether larval lipids reflect in situ feeding conditions and can thus identify match-mismatch situations. In detail, we determined larval lipid content, growth rates based on RNA:DNA ratios, and fatty acid (FA) composition during the spawning season in the Central Baltic Sea, and evaluated these in light of feeding, mortality and recruitment (which were determined in parallel within the project 'GLOBEC Germany'). Based on the opposing trend of RNA:DNA and lipid content, as well as on previous observations, we hypothesized that lipid content and current feeding conditions are largely uncoupled in the early life stages of sprat due to reduced lipid anabolism. However, lipids still provide information in several ways: (1) segmented generalised linear models proved to be a suitable tool for identifying phases of lipid catabolism during development, with the slope reflecting size-specific environmental starvation pressure. This method detected a previously identified mismatch situation with suitable prey in the early spawning season, which increased mortality of larger larvae. (2) Estimated starvation resistance, a proxy that accounts for temperature- and sizedependent metabolism, reflected the likelihood of near future starvation of individual larvae. (3) Principal component analyses on FAs identified monthly differences in diet composition. Biomarkers indicated a dinoflagellate and/or microbial loop based carbon flux to the larvae. (4) Regression analyses revealed lower docosahexaenoic acid (DHA) levels in spring, but no obvious effect on growth. Food quality was generally high, and its impact on larval survival was less evident than that of prey size suitability.
\end{abstract}

KEY WORDS: Early life history · Condition · Recruitment · Lipids · Growth · Food quality · Essential fatty acids · Trophic markers

Resale or republication not permitted without written consent of the publisher

\section{INTRODUCTION}

A century ago, Johan Hjort developed the first theories that linked recruitment of marine fish with feeding and early larval survival (Hjort 1914). As field data grew, these recruitment theories became increasingly complex. The 'critical period hypothesis' predicted that mortality during transition to first feeding (the phase when larvae are most vulnerable to starvation) will significantly determine recruitment success (Hjort 1926). The 'match-mismatch hypothesis' Cushing $(1972,1990)$ expanded the idea of prey-driven mortality to all larval stages, focussing on the relevance of spatial and temporal overlap during larval drift. More recent concepts incorporate mechanisms that focus on encounter rates and feed- 
ing success, such as small-scale patchiness of prey items and turbulence (Leggett \& Deblois 1994, Govoni 2005). Ocean hydrodynamics not only affect feeding success but also larval retention and connectivity between spatially segregated locations of different life stages, thus highly impacting recruitment success (Bakun 2010). Despite the enormous research effort in recent years, understanding recruitment processes still remains a major challenge in fisheries science.

One of the major difficulties in verifying these relationships is to reliably assess in situ feeding conditions and starvation pressure, as well as in vivo growth and condition of fish larvae. Numerous studies have tried to approach these questions by comparing environmental conditions with proxies for physiological condition, e.g. nucleic acids or lipid levels. The ratio of nucleic acids is an established tool for determining the physiological state of a larva, since it (1) is directly coupled to growth, (2) can be routinely analysed in large quantities and (3) has been calibrated for several species (Buckley et al. 2008). In contrast, field studies using total lipid (TL) content as a condition factor for fish larvae are relatively scarce due to the higher analytical effort required and the rather inconclusive results. Regional, seasonal and annual differences in lipid condition of fish larvae have been successfully linked with prey abundance (Håkanson 1989a), larval density (Zenitani 1999), maternal effects (Grote et al. 2011) as well as hydrographical conditions, i.e. water density (Guisande et al. 1998). Experimentally derived starvation thresholds for the point of no return (Håkanson 1989b) were applied to identify proportions of severely starving clupeid larvae in the field (Håkanson et al. 1994). Lipid content (determined either as content of total fatty acid [FA], TL or triacylglycerols, or as a ratio of triacylglycerols to sterols) was positively (Coombs \& Håkanson 1991 cited in Håkanson 1993, Håkanson et al. 1994) but also negatively related to larval and juvenile growth rates or its proxies (RNA:DNA) (Suthers et al. 1992, Díaz et al. 2008, 2009, 2011), making it an ambiguous tool for predicting condition. Moreover, most field studies lack information about the consequences of larval condition on survival or even recruitment, making it difficult to validate the meaning of a low lipid-derived condition factor.

The present study used sprat Sprattus sprattus from the Baltic Sea as a model organism to evaluate the potential of lipid markers as indicators of larval condition in small pelagics (Clupeiformes) in the field. Sprat larvae were collected in the Central Baltic Sea in 2002 on 4 sequential cruises from April to July, essentially covering the species-specific spawning period. In addition, data on hydrography and zooplankton composition were collected to characterise ambient environmental conditions. The study was embedded within the framework of a larger project (GLOBEC Germany), which provided not only a large amount of environmental background data, but also allowed the identification of the most successful cohorts of the spawning season and an assessment of periods of potential mismatch with suitable prey items. Specifically, we determined (1) TL content (in terms of total FAs) as an indicator of internal energy reserves, (2) RNA:DNA ratios as a proxy for somatic growth of individual sprat larvae, and (3) FA compositions as biomarkers for feeding and food quality. We used total FAs as a condition factor instead of lipid class composition, since this method also provides information on potential differences in food composition and quality. Seasonal variations of these indicators were analysed and discussed, synergistically combining our results with concurrent estimations of food preferences (Dickmann et al. 2007), mortality and growth (Voss et al. 2006) and recruitment success (Baumann et al. 2006). By integrating these results, we discuss the potential of physiological parameters to reflect the history of environmental conditions the fish larvae have encountered, and evaluate the relevance of matchmismatch processes for early larval survival.

\section{MATERIALS AND METHODS}

\section{Habitat}

The Bornholm Basin is one of the deep basins of the Central Baltic Sea and is characterised by a strong vertical stratification with a permanent deep halocline and a seasonal thermocline. It belongs to the main spawning grounds of Baltic sprat; spawning season generally lasts from February/March to August (Haslob et al. 2013). In the Basin, adults spawn in deep water layers (Voss et al. 2011) characterised by higher salinities, and the larvae that hatch from floating eggs migrate upwards into the upper $20 \mathrm{~m}$ water layers to feed (Voss et al. 2007).

\section{Sampling}

A total of 4 monthly cruise campaigns to the Bornholm Basin were carried out during the main spawning season, from April to July 2002 (Table 1). Sprat larvae were collected during all cruises at 16 differ- 
ent stations (Fig. 1) with double oblique bongo-net hauls from the surface to $5 \mathrm{~m}$ above the bottom (0.2 $\mathrm{m}^{2}$ mouth opening, $335 \mu \mathrm{m}$ mesh size, 3 knot ship speed). Samples were stored on ice and sprat larvae were randomly sorted under a stereomicroscope within $30 \mathrm{~min}$ of collection. Larvae for lipid analysis were immediately cleaned with aqua bidest and

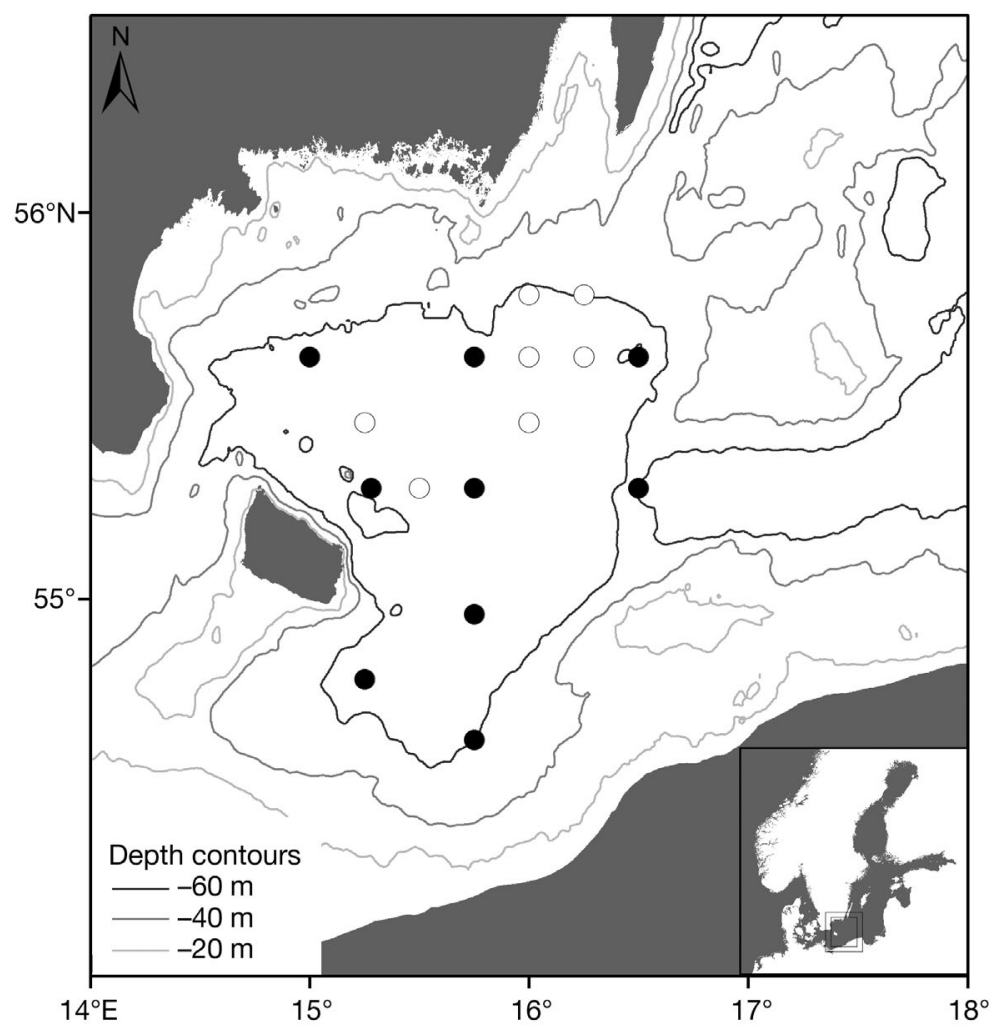

Fig. 1. Sampling areas in the Bornholm Basin of the Central Baltic Sea. White circles: areas where only sprat Sprattus sprattus larvae were sampled; black circles: sprat larvae and zooplankton were sampled. Not all stations were sampled for sprat larvae in all months. Map information was kindly provided by the Thünen Institute of Baltic Sea Fisheries (N. Plantener pers. comm.) transferred into pre-cooled glass vials, while larvae for RNA:DNA analysis were frozen in seawater-filled Eppendorf vials. The samples were stored at a constant temperature of $-80^{\circ} \mathrm{C}$.

Zooplankton samples were collected from the same bongo-net hauls and from parallel Multinet hauls, the latter only from April to June. Abundance of copepods (nauplii to CVI) as potential prey organisms was estimated from a vertically towed Multinet (Hydrobios, $0.25 \mathrm{~m}^{2}$ mouth opening, $50 \mu \mathrm{m}$ mesh size), taking separate samples at $10 \mathrm{~m}$ depth strata. At least 8 stations were sampled by the vertical Multinet on each cruise. Samples were immediately preserved in a $4 \%$ borax-buffered formaldehyde seawater solution. Subsamples of each net were analysed until at least 500 copepods were counted. Abundance was then calculated as the monthly mean of the vertically integrated station abundances. Cladocera abundance was derived from bongo-net hauls $\left(0.03 \mathrm{~m}^{2}\right.$ mouth opening, $150 \mu \mathrm{m}$ mesh size, $3 \mathrm{knot}$ towing speed) during all 4 cruise campaigns. Nauplii and smaller copepodites were important prey items for sprat larvae $<10 \mathrm{~mm}$, while adults of Acartia spp. and Centropages sp. as well as cladocerans contributed between 80 and $90 \%$ of ingested mass in sprat larvae $>10 \mathrm{~mm}$ (Dickmann et al. 2007); therefore, prey abundance was grouped as nauplii (all copepod species), small and large copepodites of only Acartia spp. and Centropages sp. as well as cladocerans. Monthly differences in abundance were assessed using a Kruskal-Wallis test followed by pairwise comparisons.

Table 1. Environmental data collected during sampling cruises. Sprat Sprattus sprattus larvae from Voss et al. (2006); average size of abundant prey in the upper $30 \mathrm{~m}$ from Dickmann et al. (2007); median availability of microzooplankton from J. van Beusekom (pers. comm.); mesozooplankton prey for preferred prey species based on Dickmann et al. (2007): copepod nauplii of Acartia spp., Centropages sp., Temora longicornis, Pseudocalanus acuspes, copepodite stage of Acartia spp. and Centropages sp. and cladocerans

\begin{tabular}{|c|c|c|c|c|c|c|c|c|c|}
\hline $\begin{array}{l}\text { Sampling } \\
\text { dates } \\
\text { (dd.mm.yy) }\end{array}$ & $\begin{array}{c}\text { Temperature } \\
\text { at } 10 \mathrm{~m} \\
\text { depth }\left({ }^{\circ} \mathrm{C}\right)\end{array}$ & $\begin{array}{l}\text { Sprat } \\
\text { larvae } \\
\left(\text { ind. } \mathrm{m}^{-3} \text { ) }\right. \\
\text { prey }(\mu \mathrm{m})\end{array}$ & $\begin{array}{l}\text { Average } \\
\text { size of } \\
\text { abundant } \\
\text { ratio }\end{array}$ & $\begin{array}{l}\text { Nauplii } \\
\text { vs. cope- } \\
\text { podite }\end{array}$ & $\begin{array}{l}\text { Microzoo- } \\
\text { plankton } \\
\left(\mu \mathrm{g} \mathrm{C}^{-1}\right)\end{array}$ & $\begin{array}{l}\text { Nauplii } \\
\text { (ind. } \mathrm{m}^{-3} \text { ) }\end{array}$ & $\begin{array}{l}\text { Copepodi } \\
\text { Small } \\
\text { (CI-CIII) }\end{array}$ & $\begin{array}{c}\text { es (ind. } \mathrm{m}^{-3} \text { ) } \\
\text { Large } \\
(\mathrm{CIV}-\mathrm{CVI})\end{array}$ & $\begin{array}{l}\text { Cladocera } \\
\text { (ind. } \mathrm{m}^{-3} \text { ) }\end{array}$ \\
\hline $04-07.04 .02$ & 6.0 & 25 & 250 & 8.1 & 5.8 & 3595 & 246 & 171 & 5 \\
\hline $06-17.05 .02$ & 7.3 & 45 & 420 & 2.7 & 6 & 3376 & 582 & 681 & 527 \\
\hline $12-20.06 .02$ & 8.7 & 10 & 630 & 0.4 & 2.8 & 2734 & 1283 & 6990 & 4364 \\
\hline $02-05.07 .02$ & 13.9 & 3 & 650 & - & - & - & - & - & 2130 \\
\hline
\end{tabular}




\section{Biochemical analyses}

Total FA (tFAs) content and composition as well as RNA:DNA ratios were analysed as proxies for nutritional condition. For lipid analysis, individual sprat larvae were transferred onto pre-cooled glass Petri dishes, photographed under the stereomicroscope and immediately placed into dry ice in order to keep thawing minimal. Total length of the larvae was analysed using the program ImageJ (Schneider et al. 2012). After freeze-drying, dry mass (DM) of sprat larvae was determined using a Sartorius micro-balance $( \pm 2 \mu \mathrm{g})$. In order to reduce condensation on the dry tissue, each larva was kept in the vacuum desiccator until weighing. Lipid extraction was performed after Peters et al. (2006) using modified protocols of Folch et al. (1957) and Kattner \& Fricke (1986). Briefly, TL were extracted using ultrasonic disruption in dichloromethane:methanol (2:1 v/v) and a washing procedure with aqueous $\mathrm{KCl}$ solution $(0.88 \%)$. For quantification of FAs, tricosanoic acid was added as an internal standard prior to extraction. Acyl groups of TL were converted into FA methyl esters (FAMEs) using methanolic sulphuric acid $(3 \%)$ at $80^{\circ} \mathrm{C}$ for $4 \mathrm{~h}$. After adding aqua bidest, FAMEs were extracted by washing the polar phase 3 times with hexane. FAMEs and fatty alcohols were separated by gas chromatography (column DB-FFAP, programmable temperature vaporiser injector, solvent vent mode), detected by flame ionisation and identified by comparing retention times with those derived from standards of known composition. Only FAs and fatty alcohols with $>0.5 \%$ of tFAs and fatty alcohols were included in the data set. All further statistical analyses were based on the 13 most important FAs (defined by a maximum value of at least $2 \%$ of tFAs within the whole data set).

Additional larvae sampled in April, May and June were analysed for RNA:DNA ratios. Essentially, total nucleic acids were extracted using a Tris-SDS-buffer and measured fluorometrically before and after RNAse treatment in a microtiter reader using ethidiumbromide. RNA and DNA concentrations were determined based on calibration curves using lambda DNA and 16S/23S ribosomal RNA. Further details on sampling and analyses are given in Voss et al. (2006).

\section{Data analyses}

\section{Energy reserves}

TL content ( $\%$ of DM) was related to larval fish length separately for each sampling month, from
April to July. An examination of the data over the entire length range indicated that the relationship was not uniformly continuous, and that different length intervals (each with a linear relationship between TL and length) could be distinguished, separated by breakpoints. Furthermore, the variance was very high at low length and relatively small at greater length, violating the assumptions of alternative non-linear regression models such as the hyperbolic functions used by Donnelly et al. (1995) and Díaz et al. (2011). Therefore, a generalised linear model (GLM) was applied assuming that the error structure followed a gamma distribution but using the identity link, meaning that the relationship between the independent variable (length) and the response variable (lipid content) was assumed to be linear. Based on this model, we then used piecewise GLMs with an automatically estimated breakpoint to account for slope changes in the linear relationship (Muggeo 2003). Starting values for the breakpoint calculation were estimated according to the observed relationship. However, due to the bootstrap restarting algorithm (here using 100 bootstrap samples, described in Wood 2001), we determined that the breakpoint estimation was not sensitive to the choice of initial values.

The resulting models were validated graphically according to the model fit (predicted values and deviance residuals vs. fitted values) and the existence of influential observations. Due to difficulties in obtaining reliable lipid content estimates for very small individuals, only measurements of larvae larger than $4 \mathrm{~mm}$ were considered in the models. Furthermore, one measurement with unrealistically high $(>30 \%$ of DM) and one with extremely low lipid content $(<3 \%$ of DM) were not considered. In June, one additional measurement with an unusually high lipid content of $>15 \%$ of DM at a larval length $>10 \mathrm{~mm}$ was identified as model outlier. These data points were also excluded from all other statistical analyses, resulting in a final number of between 60 and 149 observations per month. Finally, the broken-line models were compared to the standard GLM (continuous regression model) according to their deviance with a chi-squared test and with Akaike's information criterion (AIC) and Bayesian's information criterion (BIC). In order to avoid underfitting because only one change point was allowed, models with 2 change points were also tested. These models were on the boundary of being significantly better than models with one change point for the months of May and July. But in both cases one segment of the relationship contained only few data points, which made the estimation of the related breakpoint unreliable. Whether the slopes of the 
linear regression line segments are significantly different from zero (indicating lipid depletion or accumulation with growth) cannot be tested directly. Thus, a GLM with the same settings was fitted separately to the data of each segment, and the slope parameter was tested for significance with a $t$-test.

In a second step, we calculated a length-specific proxy for starvation resistance for each month based on TL content and temperature dependent metabolism. Starvation resistance was defined as the time period during which a larva could theoretically fuel its standard metabolism only by internal lipid reserves. Energetic costs for foraging or utilization of other energy sources were not included. The amount of storage lipid for each larva was estimated via the difference between the individual and the potentially minimum lipid content (derived from the running $10 \%$ trajectory) observed at the respective size. This depot lipid was converted to energy (energy equivalent of $9 \mathrm{cal} \mathrm{mg}^{-1}$ ). Negative energy depots were treated as entirely depleted. Energy requirements of the standard metabolism as a function of larval DM and in situ temperature at $10 \mathrm{~m}$ depth (Table 1) were estimated after Daewel et al. (2008) and references therein. For each month, a running median of starvation resistance was calculated.

\section{Growth}

Cohort growth rates were estimated based on the running median of RNA:DNA ratios of individual sprat larvae, which were sampled in parallel in April, May and June. Further details on sampling, sample analyses and month- and length-specific RNA:DNA ratios are given in Voss et al. (2006). Here, we used RNA:DNA to estimate growth rates, i.e. the ratios were standardised according to Caldarone et al. (2006) using slope ratios of the standard curves of 2.2. These standardised RNA:DNA ratios (sRD) were converted to mass-specific growth $(G$, in \%) rates using a temperature $(T)$ dependent, multi-species growth model (Buckley et al. 2008), which includes an interaction term, a sRD main term and an intercept: $G=$ $(0.0145+0.0044 \times T) \times \mathrm{sRD}-0.078$.

\section{Feeding and food quality}

Monthly means and standard deviations of the 13 most important FAs were calculated for small $(<8 \mathrm{~mm})$ and large $(>8 \mathrm{~mm})$ sprat larvae. This cut-off size roughly corresponds to the size at which larger larvae were mostly lipid-depleted in all months. This simplification was chosen in order to reduce data but still account for the influence of size and lipid content (which was on average higher in smaller larvae) on the FA composition. A principal component analysis (PCA) was performed using the software SPSS to characterise the trophic marker compositions in each month. For this, the FA composition of each larva was transformed using an arc sine square root. Median values of the PC1 and PC2 were then calculated for size classes $4-6,6-8,8-10,10-12,12-14$ and $>14 \mathrm{~mm}$.

Larval content of docosahexaenoic acid (DHA) was used as a potential proxy for recent food quality. However, the relative content of DHA is sensitive to the ratio of polar and neutral lipids. Due to the high individual variability of TL levels, we performed a regression analysis with the proportion of DHA in relation to tFAs as response, and the TL content in larvae sensu mass as explanatory variable. Since the response variable assumes values in the standard unit interval, and are thus typically heteroscedastic (meaning that they display most variation around the mean), we used a weighted beta regression model with the standard logit link function (Ferrari \& Cribari-Neto 2004, Cribari-Neto \& Zeileis 2010). Additionally, seasonality in this relationship was considered by using sampling months as a factor with 4 levels (April, May, June, July). The goodness-of-fit was assessed graphically, and outliers were assessed by Cook's distance and leverage. Two measurements in May were not considered for the regression analysis due to their high leverage. The minimum adequate model was selected by comparing nested models with the help of the likelihood ratio test. For nested models, sampling months were summarised into 1 factor level if no significant differences were detected between them.

To estimate a potential enrichment of DHA within the food chain, relative DHA values of seston and Acartia spp. females were analysed during the study period. Furthermore, several food quality characteristics for Acartia spp. females were calculated. For further details on sampling, sample analyses and FA composition of seston and copepods, refer to Peters et al. $(2006,2013)$.

\section{RESULTS}

\section{Environment}

Temperature at $10 \mathrm{~m}$ water depth (the approximate depth with the vertically highest abundance of sprat larvae; Voss et al. 2006) increased continuously from 
$6.0^{\circ} \mathrm{C}$ in April to $13.9^{\circ} \mathrm{C}$ in July (Table 1). Prey field composition varied between the 4 months, which is reflected in a considerable increase in average zooplankton size in the field (from 250 to $650 \mu \mathrm{m}$ ) as well as in the ratio between nauplii and copepodites/cladocerans. While the abundance of copepod nauplii was relatively stable between 2700 and 3600 ind. $\mathrm{m}^{-3}$ (monthly differences were not significant), larger prey items increased continuously with season. Small copepodites increased from ca. 250 to 1300 ind. $\mathrm{m}^{-3}$ from April to June (significant minimum in April, $\mathrm{p}<0.02$ [April vs. May] and $\mathrm{p}<0.001$ [April vs. June]), while larger prey items exhibited a significantly lower abundance in April ( $\mathrm{p}<$ 0.001 ) and increased by an order of magnitude in June. Microzooplankton biomass was not significantly different between months due to strong spatial variability; however, the highest values were observed in April (data not shown).

\section{Energy reserves and growth}

Lipid contents of sprat larvae ranged from 4 to $25 \%$ of DM. In order to describe the relationship between larval length and TL content, broken-line regression models with 1 breakpoint were fitted separately to the data of each sampling month (Fig. 2). These models were found to be significantly better than the ordinary linear models, and no violations of the model assumptions were detected.

The resulting relationships from each sampling month indicate the existence of 3 phases in larval development (Table 2). In the initial phase, when larvae are still small, no relationship exists between TL content and larval length. On average, the lipid content is highest during this early period but also shows the strongest variability. This phase was observed in April, when the performance of the brokenline regression model was only mar-
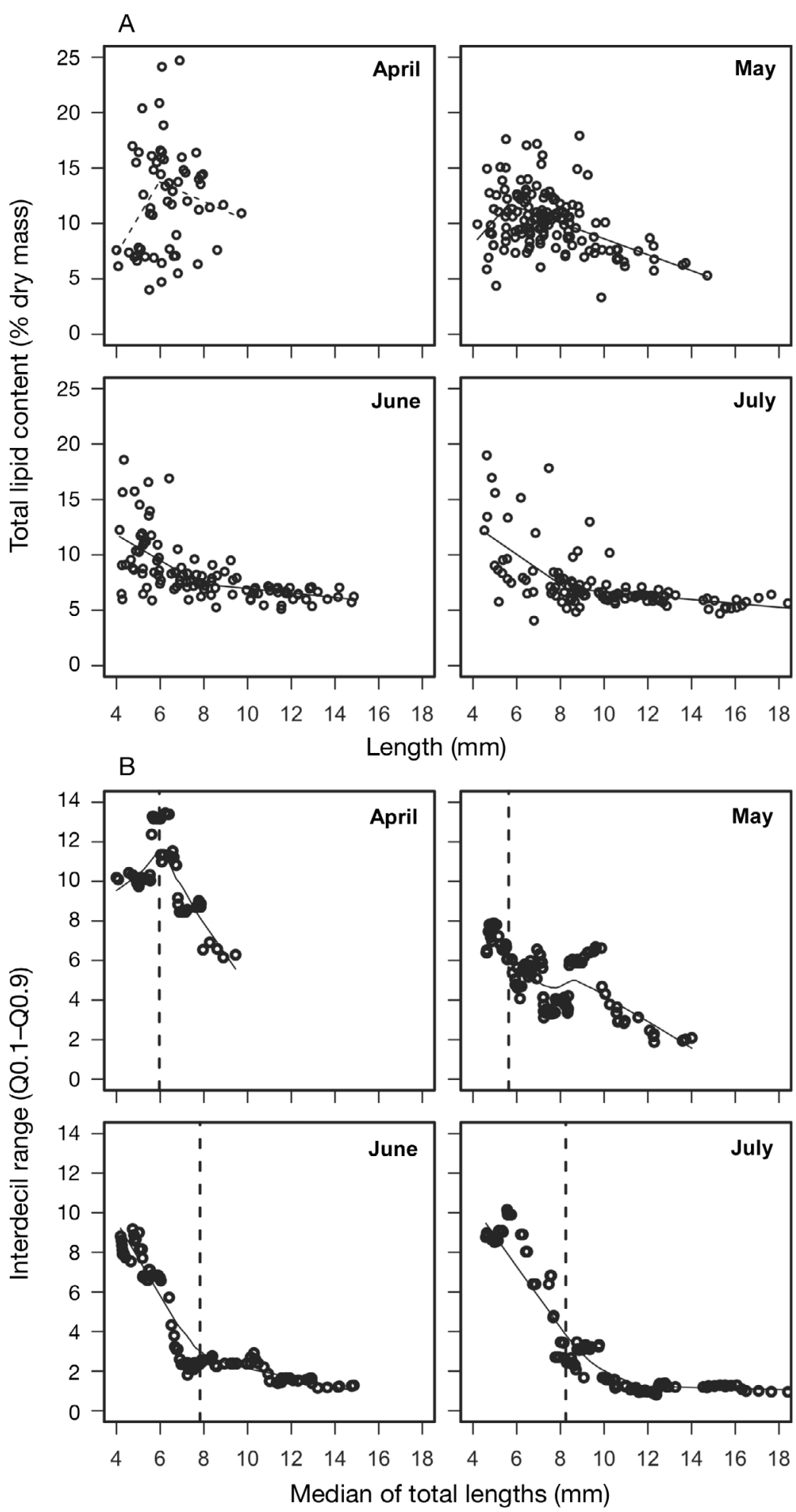

Fig. 2. (A) Broken-line regression models showing the relationship between total lipid content and size of individual sprat Sprattus sprattus larvae for the months April $(n=60)$, May $(n=149)$, June $(n=109)$ and July $(n=118)$; circles: measured values; dashed line: slope of regression line (not significant); solid line: slope of regression line (significant). (B) Size-dependent variance; circles: variance as running interdecil range between the 10th and 90th percentile (Q0.1-Q0.9) vs. size given as running median; line: Lowess smoother for visualisation; dashed line: breakpoint given by broken-line regression model 
Table 2. Parameters of broken-line regression models for sprat Sprattus sprattus size-dependent lipid content: $\mathrm{p}$-value = significance of break point compared to standard generalised linear model (GLM) using chi-squared test. Phase I = no observable lipid depletion, II = strong lipid depletion, III = depleted lipid reserves (for further details of conceptual model refer to 'Materials and methods' and 'Discussion'). Slope $=$ slope of regression line during the respective phase; $\mathrm{p}$-value (slope) $=$ significance of slope tested for each segment separately using a $t$-test. ${ }^{*} \mathrm{p}<0.05,{ }^{* *} \mathrm{p}<0.01,{ }^{* * *} \mathrm{p}<0.001$

\begin{tabular}{|c|c|c|c|c|c|}
\hline Month & $\begin{array}{l}\text { Break at } \\
\text { length } \\
(\mathrm{mm})\end{array}$ & $\begin{array}{c}\mathrm{p} \text {-value } \\
\text { (segmented } \\
\text { GLM) }\end{array}$ & Phase & Slope & $\begin{array}{l}\text { p-value } \\
\text { (slope) }\end{array}$ \\
\hline April & 5.96 & $0.046^{*}$ & $\begin{array}{c}\text { I } \\
\text { II }\end{array}$ & $\begin{array}{r}3.33 \\
-0.82\end{array}$ & $\begin{array}{l}0.12 \\
0.29\end{array}$ \\
\hline July & 8.25 & $<0.001^{* * *}$ & $\begin{array}{l}\text { I } \\
\text { II }\end{array}$ & $\begin{array}{r}2.23 \\
-0.72\end{array}$ & $\begin{array}{l}0.16 \\
<0.001^{* * *}\end{array}$ \\
\hline May & 5.63 & $0.004^{* *}$ & $\begin{array}{c}\text { II } \\
\text { III }\end{array}$ & $\begin{array}{l}-1.16 \\
-0.20\end{array}$ & $\begin{array}{l}<0.001^{* * *} \\
<0.001^{* * *}\end{array}$ \\
\hline June & 7.82 & $<0.001^{* * *}$ & $\begin{array}{l}\text { II } \\
\text { III }\end{array}$ & $\begin{array}{l}-1.36 \\
-0.18\end{array}$ & $\begin{array}{r}0.005^{* *} \\
<0.001^{* * *}\end{array}$ \\
\hline
\end{tabular}

also proteins (Ferron \& Leggett 1994), (2) storage lipids are also converted into somatic growth (Kamler 2008) and (3) the estimation is based on the routine metabolism only, neglecting any further losses based on mobility and digestion. However, it is one approach to evaluate the energy content under prevailing environmental conditions. Starvation resistance was highest in April, with a median of up to $5 \mathrm{~d}$ (Fig. 3). According to the progression in lipid content, no decrease in starvation resistance was observed. Smaller larvae in May $(<9 \mathrm{~mm})$ were on average able to survive starvation for a maximum of $2.5 \mathrm{~d}$, whereas larger larvae (>9 $\mathrm{mm}$ ) could only starve for $1 \mathrm{~d}$. Starvation resistance for larvae in June and

ginally better than the continuous regression line, and in the first segment of May (Fig. 2A). The slope was not significantly different from zero for any of these segments, indicating that no clear dependency between length and lipid content could be detected for the respective length range. In the second phase, lipid content decreased linearly with larval length, but breakpoint and slope were dependent on the sampling month. In May, lipid depletion was observed from $5.6 \mathrm{~mm}$ onwards, whereas in June and July a clear decrease in the lipid content was found already for the smallest larvae (i.e. from $4 \mathrm{~mm}$ onwards), with the strongest decrease in July. The breakpoint identified in June and July at 7.8 and $8.3 \mathrm{~mm}$, respectively, indicates the transition to a third phase. In this phase, the slope of the regression line is only small and the lipid content possibly converges to a lower level of approximately $5 \%$ of DM. Data variability was generally high for small larvae and decreased with size during all months (Fig. 2B). The interdecil range generally followed a hyperbolic progression, and the minimum was reached approximately at the transition to the third phase in the GLM.

In order to assess the meaning of the respective larval lipid content (metabolic turnover rates depend on both temperature and body size), we converted the TL into a proxy for starvation resistance, given as the estimated maximum number of days a larva is able to fuel its routine metabolism only by internal lipid reserves. It is important to note that this is an absolutely theoretical value, and does not reflect the true period that the fish larvae could sustain starvation, since (1) fish larvae catabolize not only lipids but (especially) July, when water temperature was highest at ca. $14^{\circ} \mathrm{C}$, was very low, and varied between 0 and $1 \mathrm{~d}$ (except for larvae $<6 \mathrm{~mm}$ in June). Estimated mass-specific growth rates based on protein metabolism (RNA:DNA ratios) in April and May showed a similar pattern according to larval length and increased with size from 0 to $0.05 \mathrm{~d}^{-1}$, while growth rates in July were generally higher and increased steadily from 0.05 to $0.25 \mathrm{~d}^{-1}$. Specific RNA:DNA ratios increased with size in all months, and medians were higher for larvae between 6 and $12 \mathrm{~mm}$ in April and May than in July. For further details on RNA: DNA ratios refer to Voss et al. (2006).

\section{Feeding and food quality}

In order to determine month- and size-specific differences in the feeding histories of sprat larvae, we analysed the FA composition and the content of essential FAs in sprat larvae as well as in Acartia spp. as a main prey item. Principal FAs in the sprat larvae (although with significant differences between months and size classes) were 16:0, 18:0, 18:1(n-9), 18:2(n-6), 20:5(n-3) and 22:6(n-3), which together accounted for 80 to $85 \%$ of tFAss (Table 3 ). The differences were, however, not independent of TL content; thus FA compositions are presented for smaller larvae $(<8 \mathrm{~mm})$ which had on average a higher lipid content, and larger larvae ( $>8 \mathrm{~mm})$, which on average were already lipid-depleted. The highly unsaturated FAs 20:5(n-3) and 22:6(n-3) varied between $9-14 \%$ and $18-37 \%$ of tFAs, respectively, in each 

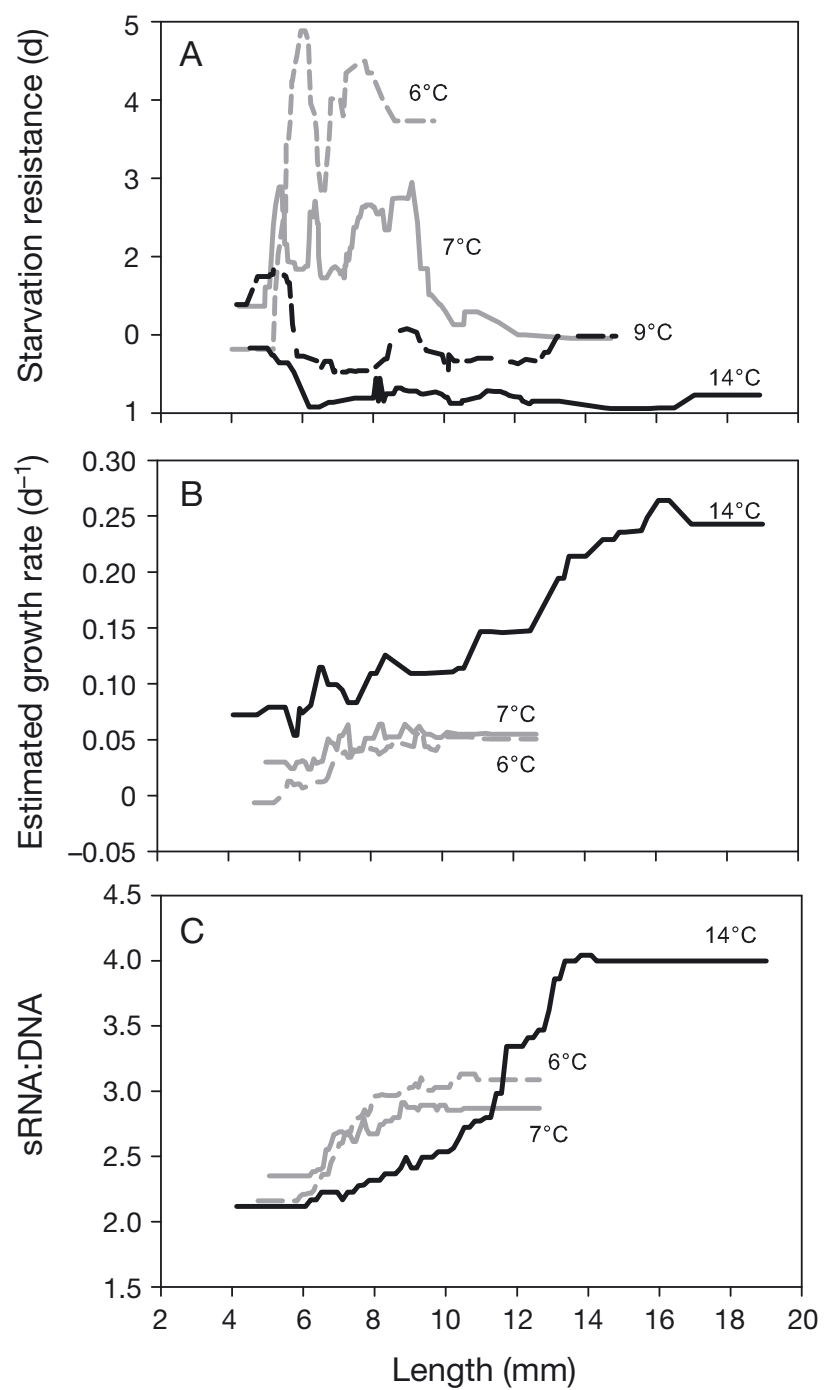

month with higher percetages in the larger size class. Trophic markers for a diatom-based food web, $16: 1(n-7)$ and 18:1(n-7), contributed on average only $1 \%$ and $2-3 \%$ to the tFAs, respectively. The trophic marker patterns were generally characterised by C18-unsaturated FAs, especially by $18: 1(n-9)$ (6 to $13 \%$ of tFAs), $18: 2(n-6)$ (4 to $7 \%$ of tFAs) and 18:4 (n-3) (2 to $4 \%$ of tFAs).

PCA revealed patterns in the FA marker compositions (Fig. 4). The first principal axis (PC1) mainly separated larvae according to size and explained $33 \%$ of the observed variability. Higher lipid levels as well as high levels of 18:1(n-9), 16:1(n-9), 16:0 and 18:0 were characteristic for smaller larvae, contrasting with higher levels of 20:5(n-3) and 22:6(n-6) in larger larvae. The transition from positive to negative PC1 loadings occurred between different size classes in April (no transition), May (8 $\mathrm{mm})$ and June/July $(6 \mathrm{~mm})$, in accordance with the observed differences in lipid depletion. The second axis (PC2) separated larvae according to season and explained $20 \%$ of the observed variance with higher levels of polyunsaturated C18-FA and 18:1(n-7) in all April larvae as well as in smaller larvae in May. The distribution of sam-

Fig. 3. (A) Estimated sprat Sprattus sprattus starvation resistance based on lipid content, (B) calculated weight-based growth rates based on RNA:DNA ratios and (C) sRNA:DNA ratios as moving median vs. larval size, for the months of April $\left(6^{\circ} \mathrm{C}\right.$, grey dashed line), May $\left(7^{\circ} \mathrm{C}\right.$, grey solid line), June $\left(9^{\circ} \mathrm{C}\right.$, black dashed line) and July $\left(14^{\circ} \mathrm{C}\right.$, black solid line); no growth rate or sRNA:DNA ratios are given for June; further details in the 'Materials and methods'

Table 3. Fatty acid (FA) composition (\% of total FAs) of small $(<8 \mathrm{~mm})$ and large ( $>8 \mathrm{~mm})$ sprat Sprattus sprattus larvae in April, May, June and July. Data are given as mean $\pm \mathrm{SD} ; \mathrm{N}=$ number of larvae; only the most important FAs are presented defined by a maximum value of at least $2 \%$ of total FAs within the whole data set

\begin{tabular}{|c|c|c|c|c|c|c|c|c|}
\hline \multirow[b]{3}{*}{$\mathrm{N}=$} & \multicolumn{2}{|c|}{ April } & \multicolumn{2}{|c|}{ May } & \multicolumn{2}{|c|}{ June } & \multicolumn{2}{|c|}{ July } \\
\hline & $<8 \mathrm{~mm}$ & $>8 \mathrm{~mm}$ & $<8 \mathrm{~mm}$ & $>8 \mathrm{~mm}$ & $<8 \mathrm{~mm}$ & $>8 \mathrm{~mm}$ & $<8 \mathrm{~mm}$ & $>8 \mathrm{~mm}$ \\
\hline & 56 & 4 & 99 & 50 & 62 & 48 & 31 & 87 \\
\hline $14: 0$ & $1.1 \pm 0.6$ & $1.1 \pm 0.2$ & $1.0 \pm 0.5$ & $1.0 \pm 0.4$ & $1.3 \pm 0.6$ & $1.1 \pm 0.4$ & $0.9 \pm 0.5$ & $0.9 \pm 0.4$ \\
\hline $16: 0$ & $23.1 \pm 2.3$ & $23.6 \pm 1.3$ & $21.2 \pm 2.2$ & $19.6 \pm 2.2$ & $21.5 \pm 2.5$ & $20.3 \pm 2.1$ & $19.6 \pm 3.5$ & $19.1 \pm 1.9$ \\
\hline $18: 0$ & $9.1 \pm 2.1$ & $7.5 \pm 0.9$ & $8.0 \pm 1.9$ & $5.6 \pm 2.1$ & $9.6 \pm 2.5$ & $5.8 \pm 1.6$ & $11.7 \pm 4.1$ & $6.2 \pm 1.1$ \\
\hline $16: 1(n-7)$ & $1.3 \pm 0.3$ & $1.6 \pm 0.3$ & $1.0 \pm 0.3$ & $1.2 \pm 0.3$ & $1.1 \pm 0.3$ & $1.1 \pm 0.3$ & $1.0 \pm 0.3$ & $1.0 \pm 0.3$ \\
\hline $16: 1(n-9)$ & $2.8 \pm 1.6$ & $1.8 \pm 0.4$ & $2.0 \pm 1.4$ & $1.0 \pm 1.4$ & $2.9 \pm 2.5$ & $0.7 \pm 0.4$ & $1.6 \pm 1.0$ & $0.6 \pm 0.3$ \\
\hline $18: 1(n-7)$ & $2.9 \pm 0.4$ & $3.2 \pm 0.1$ & $2.6 \pm 0.2$ & $2.4 \pm 0.4$ & $2.4 \pm 0.4$ & $2.3 \pm 0.4$ & $2.1 \pm 0.3$ & $2.0 \pm 0.2$ \\
\hline $18: 1(n-9)$ & $12.9 \pm 4.2$ & $10.2 \pm 0.8$ & $12.1 \pm 2.0$ & $11.4 \pm 1.5$ & $10.8 \pm 3.5$ & $6.7 \pm 1.6$ & $9.2 \pm 2.2$ & $6.3 \pm 0.9$ \\
\hline $18: 2(n-6)$ & $6.9 \pm 1.6$ & $7.4 \pm 1.0$ & $6.2 \pm 1.7$ & $4.7 \pm 2.4$ & $4.7 \pm 2.0$ & $4.4 \pm 1.4$ & $5.4 \pm 1.9$ & $3.8 \pm 2.1$ \\
\hline $18: 3(n-3)$ & $2.4 \pm 0.7$ & $2.4 \pm 0.2$ & $2.0 \pm 0.7$ & $1.3 \pm 0.5$ & $1.4 \pm 0.6$ & $2.0 \pm 0.3$ & $1.5 \pm 0.6$ & $1.8 \pm 0.2$ \\
\hline $18: 4(n-3)$ & $3.7 \pm 1.5$ & $4.1 \pm 0.4$ & $3.1 \pm 0.8$ & $2.7 \pm 2.0$ & $1.9 \pm 1.2$ & $2.5 \pm 0.9$ & $2.2 \pm 1.4$ & $2.8 \pm 1.8$ \\
\hline $20: 5(n-3)$ & $11.1 \pm 3.1$ & $13.9 \pm 1.2$ & $10.7 \pm 1.3$ & $10.2 \pm 1.1$ & $9.1 \pm 1.6$ & $11.2 \pm 1.0$ & $8.6 \pm 1.9$ & $10.9 \pm 1.3$ \\
\hline $22: 5(n-3)$ & $1.1 \pm 0.5$ & $1.5 \pm 0.1$ & $1.0 \pm 0.5$ & $0.7 \pm 0.3$ & $0.9 \pm 0.4$ & $0.9 \pm 0.2$ & $1.3 \pm 0.5$ & $1.0 \pm 0.3$ \\
\hline $22: 6(n-3)$ & $17.5 \pm 3.2$ & $19.0 \pm 1.8$ & $26.0 \pm 6.1$ & $33.8 \pm 6.6$ & $27.8 \pm 6.5$ & $35.6 \pm 3.8$ & $27.9 \pm 7.7$ & $37.4 \pm 3.7$ \\
\hline
\end{tabular}




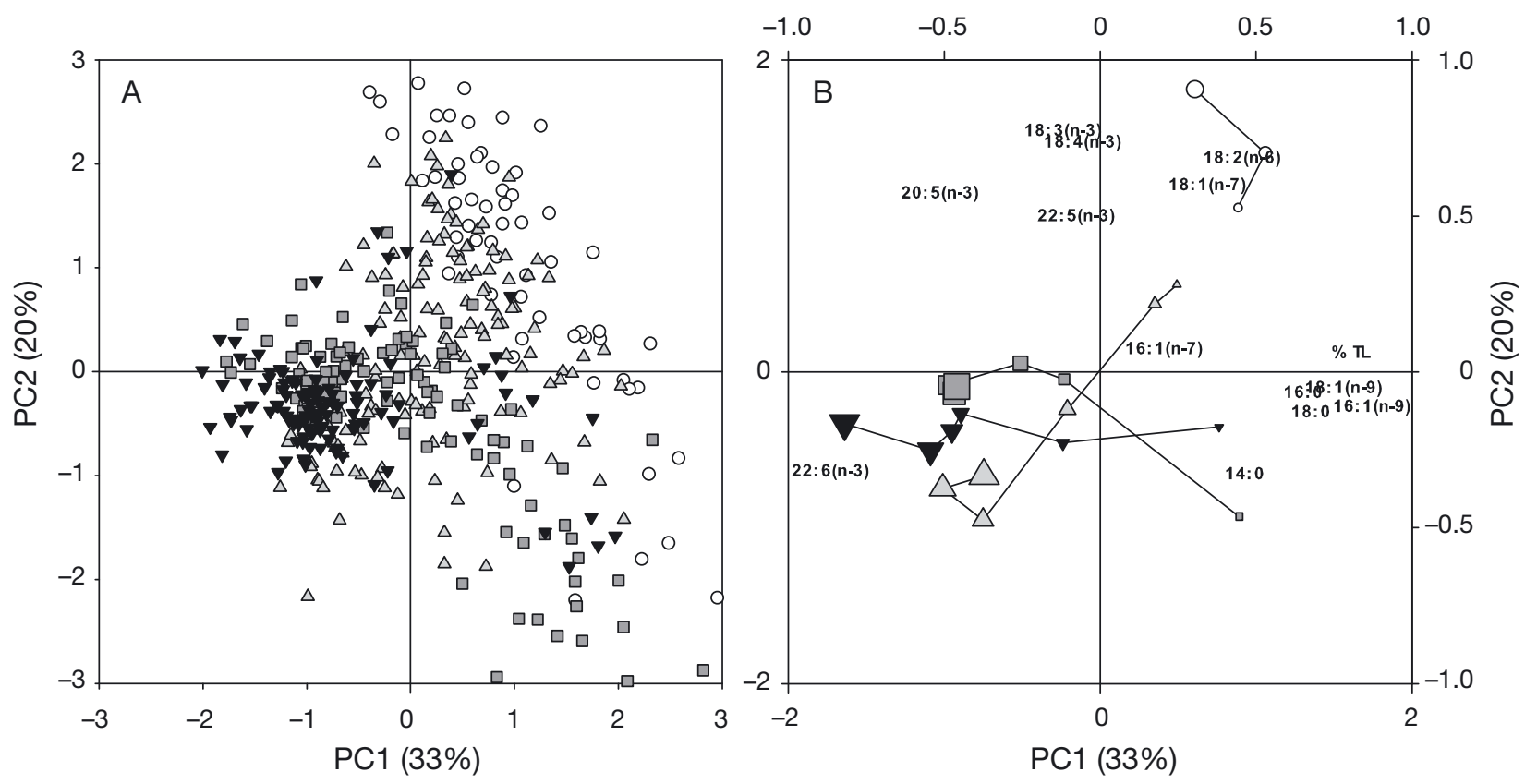

Fig. 4. Principal component analysis (PCA) on the \% of total fatty acids (tFAs) of individual sprat Sprattus sprattus larvae in April (white circles), May (light grey triangles), June (dark grey squares) and July (black triangles); (A) sample plot; (B) sample plot and variable plot superimposed, with scales adjusted to combine plots (sample plot: scale extends from -2 to +2 ; variable plot: from -1 to +1$)$. Samples are presented as median values of the PC1 and PC2 for all larvae in the size classes 4-6, 6-8 and 8-10 mm in April, and 4-6, 6-8, 8-10, 10-12, 12-14 and >14 mm in May, June and July. Symbol size increases with larval size

ples showed strong overlaps between months, but also a clear transition from the first (C18-FAs) to the third quadrant (DHA).

The essential FA DHA was considered separately, and a significant decrease with TL was observed in all sampling months (Fig. 5). Testing TL and the factor 'month' as explanatory variables in a beta-regression model showed that estimates for the linear predictor were very similar for the months of May, June and July. Thus, in the resulting most parsimonious model, the 4-level factor 'month' was replaced by a 2-level factor: the first level included data only from the first sampling month (April), whereas the second level comprised data collected in May, June and July. In April, the relative decrease of DHA was comparably small and the proportion of DHA was in the range of 10 to $25 \%$ of tFAs. In May, June and July, the maximum value of DHA was $44 \%$ of tFAs, which cooccurred with a low lipid content of approximately $5 \%$ of DM. Thus, the negative relationship with TL is less pronounced for larvae hatched early in the year (i.e. April), than for those collected between May and July (Fig. 5). Furthermore, the percentage of DHA was generally higher for later-hatched larvae. Due to the smaller slope in April, this seasonal difference becomes less pronounced in lipid-rich larvae, indicating that it is mainly the structural lipids that are affected by lower DHA levels. No corresponding cor- relation was observed for eicosapentaenoic acid (EPA). Arachidonic acid (ARA) levels were always below $1 \%$ of tFAs (data not shown).

Comparison of DHA content (\% TL) in seston, copepods and sprat larvae showed a DHA enrichment of on average $10 \%$ with every trophic level, assuming Acartia spp. as a major prey item (Fig. 6). A similar enrichment did not occur for other polyunsaturated FA (PUFA) markers (data not shown). Despite the moderate lipid content of Acartia spp., lipid quality is relatively high, with PUFAs providing $55 \%$ of tFAs and a DHA:EPA ratio of 1.4 (Table 4). However, ARA levels in the copepods were generally below $0.5 \%$ of tFAs. For further information on FA data of seston or copepods refer to Peters et al. (2013).

\section{DISCUSSION}

\section{Energy reserves and growth}

Starvation and predation are the two most serious and pervasive threats to fish larvae during early development (Anderson 1988). The physiological state of the larvae can significantly influence the impact of these threats, and understanding the causes and consequences of differences in larval condition sensu fitness will help to clarify variability 


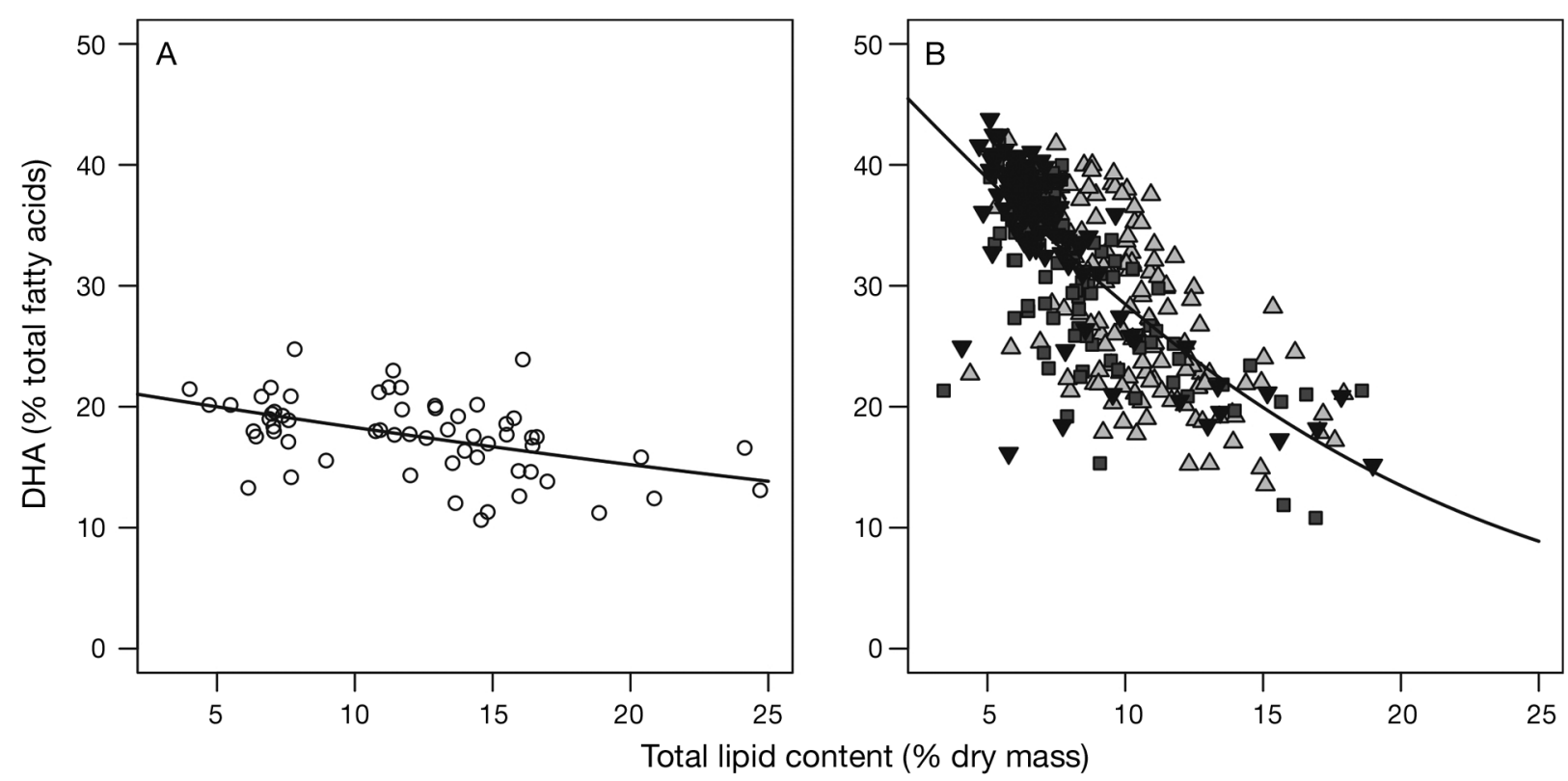

Fig. 5. Proportion of docosahexaenoic acid (DHA) versus total lipid content in sprat Sprattus sprattus during (A) April and (B) May (light grey triangles), June (dark grey squares) and July (black triangles). Weighted beta regression models with logitlink function were fitted for April and for the pooled data of May, June and July

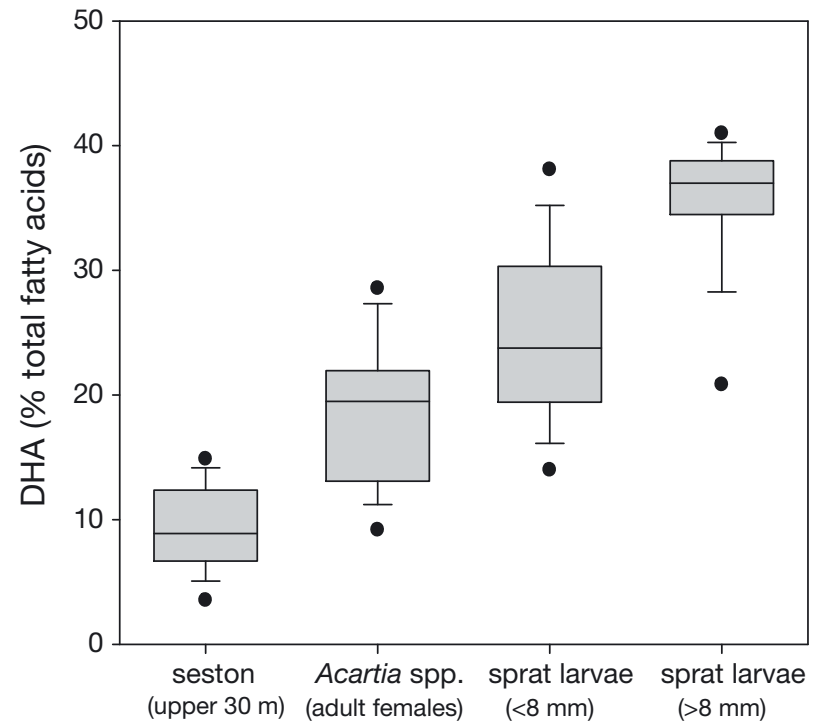

Fig. 6. Proportion of docosahexaenoic acid (DHA) in April, May, June and July for seston in the upper $30 \mathrm{~m}$, adult females of Acartia spp. and small $(<8 \mathrm{~mm})$ and large $(>8 \mathrm{~mm})$ sprat Sprattus sprattus larvae, as box-and-whisker plot showing the median (line), interquartile range (box), interdecil range (whiskers) and the 5th and 95th percentile (dots); further details on fatty acid composition of seston and Acartia spp. are given in Peters et al. (2013)

in recruitment success. This study aimed to evaluate whether lipid markers represent a suitable proxy for larval condition of small pelagic fish using sprat as a model organism. To that end, we investigated sizespecific monthly differences in larval energy reserves
Table 4. Fatty acid (FA) quality indicators of Acartia longiremis females. Mean = annual mean of monthly means; Min. = lowest monthly mean; Max. = highest monthly mean; tFAs = total fatty acids; PUFA = polyunsaturated fatty acids; EPA $=$ eicosapentaenoic acid $, 20: 5(n-3) ;$ DHA = docosahexaenoic acid, 22:6(n-3); ARA = arachidonic acid, 20:4(n-6). For further details refer to Peters et al. (2013)

\begin{tabular}{|lccc|}
\hline & Mean & Min. & Max. \\
\hline${\text { tFAs }\left(\mu \text { ind. }^{-1} \text { ) }\right.}$ & 0.3 & 0.2 & 0.5 \\
PUFAs (\% tFAs) & 55 & 50 & 57 \\
DHA (\% tFAs) & 19 & 12 & 27 \\
EPA (\% tFAs) & 14 & 9 & 19 \\
ARA (\% tFAs) & $<0.5$ & $<0.5$ & 0.5 \\
DHA:EPA & 1.4 & 1 & 1.8 \\
\hline
\end{tabular}

and related them to growth rates and potential survival in the context of food abundance and quantity.

Lipid levels varied between approximately $5 \%$ and $25 \%$ of DM, which is in the common range observed for clupeid larvae (Gatten et al. 1983, Tocher et al. 1985). The dispersion of data (determined as the 10th to 90th percentile interval) was clearly related to size, with high variability for small larvae that decreased nearly asymptotically with size. Similarly, average lipid levels were high in small larvae and decreased with increasing larval size during all months (except for April, when only larvae <10 mm were found). Internal energy reserves at small larval size are primarily of maternal origin and serve as buffer in times 
of food deprivation. According to the growth-mortality hypothesis, fast-growing larvae are positively selected, since the risk of predation decreases with size (Ware 1975, Shepherd \& Cushing 1980). A strategy to store ingested energy instead of transferring it to somatic growth would thus be an evolutionary disadvantage for a sprat larva in an environment with high predation pressure. Reduced lipid accumulation during early larval development is therefore very likely and has also been observed in species such as herring (Ehrlich 1974) and anchovy (Díaz et al. 2008, 2009). Although we did not follow a specific cohort, information about the ontogenetic development of larval condition can be deduced when examining a wide size range of samples within a short time frame. The observed decrease with size in both lipid content and variability indicates that individual lipid reserves of sprat larvae are initially depleted and not refilled during early development ( $<25 \mathrm{~d}$ post hatch). Lipid reserves in herring decreased constantly with growth, both in the field (Folkvord et al. 1996) and under experimental ad libitum feeding conditions (Ehrlich 1974, Gatten et al. 1983). In both experiments, lipid contents showed an almost hyperbolic progression with minimum values after $40 \mathrm{~d}$ post hatch or at $20 \mathrm{~mm}$ length, respectively, and a refill of lipid reserves thereafter. Similar conclusions were drawn by Díaz et al. (2011) based on a comprehensive data set on lipid, protein and nucleic acid contents of sardine larvae in the Bay of Biscay. While lipid levels decreased with larval size, RNA:DNA ratios increased, apparently reflecting a favoured energy transfer towards somatic growth.

Lipid-length relationships were described using a segmented GLM and not by hyperbolic functions as described in Donnelly et al. (1995) and Díaz et al. (2008, 2011). We chose this approach because the assumptions of a non-linear regression model in relation to the distribution of the residuals would have been violated, and we aimed at distinguishing certain phases in larval development. By using brokenline regression we were able to recognise 3 subsequent phases with (1) no significant relationship, i.e. no obvious change in average lipid content with size, (2) a highly significant negative relationship, i.e. a phase of strong lipid depletion, and finally (3) a significant negative relationship with a less pronounced slope. Even though the model indicates the existence of 3 phases, the first phase may be artificial. While lipid quantification is least precise for small specimens, the individual variation in lipid content is also highest at small body sizes, and the depletion of lipid depots already exists pre-hatch (Desvilettes et al.
1997) and increases after hatching (Martell et al. 2005). However, this lipid utilization is not directly detectable at low turnover rates and low temperatures, as they have been observed in April and partly in May. The intensity of lipid catabolism during phase II apparently reflects the intensity of environmental starvation pressure on the respective size range. Each larva with depleted lipid reserves has already passed through at least one period of insufficient food supply. The probability of experiencing food deprivation for the first time increases during development, leading to the strong decrease in median lipid content with size and in the respective variability.

Depending on food availability and quality as well as on the energy demand driven by the ambient temperature regime, the rate of lipid depletion increased from May to July. Depot lipids were completely depleted in June and July at approximately $8 \mathrm{~mm}$. Since there were almost no larvae larger than $12 \mathrm{~mm}$ present in May, the predicted timing of lipid depletion is less reliable, but lipid contents seem to level off earliest at 10 to $12 \mathrm{~mm}$ length. Even though the model indicates a steady decrease of lipid contents in the third phase, the slope is very moderate and we assume that lipid levels typically approach a minimum level of approximately $5 \%$ of DM, which is predetermined by the sum of essential structural lipid components such as membrane molecules or sterols. This roughly corresponds to the $5 \%$ polar lipids found in $36 \mathrm{~d}$ old herring larvae (Tocher et al. 1985). Accordingly, the lowest lipid levels at all size classes (defined by the $10^{\text {th }}$ percentile trajectories) varied between 5 and $7 \%$ of DM, and size-related changes seem to be primarily determined by morphological constraints.

Yolk absorption is strongly driven by temperature (Martell et al. 2005) and is completed in Baltic sprat larvae at a larval size of 5 to $5.5 \mathrm{~mm}$, which is reached after $<10 \mathrm{~d}$ at temperatures occurring in June and July, and around 12 to $14 \mathrm{~d}$ at temperatures in April and May (Petereit et al. 2008). Although the seasonal increase in depletion rate was probably primarily driven by higher temperatures (which rose from $6^{\circ} \mathrm{C}$ in April to $14^{\circ} \mathrm{C}$ in July), this cannot be explained by a metabolic increase alone. According to temperature, the estimated daily caloric demands increased from April to May and from May to June by ca. 14\%, but they were $60 \%$ higher in July than in June. These differences are neither reflected in the starvation resistance nor in the estimated growth rates. Small sprat larvae (6 to $10 \mathrm{~mm}$ ) feed primarily on copepod nauplii (Dickmann et al. 2007) and the 
prey field remained relatively constant during the 4 months. Thus, prey availability may have been insufficient to compensate for increased metabolic requirements in June and July. Starvation resistance dropped rapidly at a length of around $6 \mathrm{~mm}$. Data on stomach contents indicated that these first-feeding larvae are most likely food limited most of the time, due to low feeding success and rapidly increasing niche breadth (Dickmann et al. 2007). The most important food items for larger larvae (>10 mm) were copepodids of Acartia spp. and Centropages sp. as well as cladocerans (Dickmann et al. 2007). In April and May, their abundances were an order of magnitude lower than in June; accordingly, starvation resistance in these months dropped at around $10 \mathrm{~mm}$ length, indicating a mismatch situation due to a lack of appropriate food items. Similarly, a comparison of larval abundance in the study area in 2002 showed that the estimated spring mortality increased for larvae from $11 \mathrm{~mm}$ onwards, in contrast to higher survival rates for summer larvae (Voss et al. 2006). This is in agreement with the observed patterns in energy reserves. This match-mismatch situation during the spawning period likely has strong implications for the recruitment process. The estimated temporal window of survival, which was back-calculated from otolith microstructures of the young-of-the-year in autumn 2002 and corrected for hydrodynamic transport, was relatively small compared to the spawning season and included only larvae that hatched in June (Baumann et al. 2006). A correlation analysis between different life stages and year-class strength indicated that the period from late larval to early juvenile stages seems to be the most critical phase for sprat recruitment in the Central Baltic Sea (Köster et al. 2003).

The pronounced size-related variance observed in the data also has - aside from its ecological interpretations - strong methodological relevance. In order to reliably estimate mean larval condition, large sample sizes, especially for small first-feeding larvae, are necessary. For the smallest size classes, interpretation of lipid levels as a condition factor must be performed with care. Our study suggests that individual lipid levels are a suitable proxy for (1) feeding history, i.e. indicating whether the larva has already experienced a prey field that was insufficient to compensate for temperature-dependent metabolic requirements, as well as (2) energy depots, which in turn reflect the likelihood of near-future starvation. However, low lipid content does not necessarily correlate with suboptimal feeding or growth conditions. Consequently, experimental approaches linking the lipid-based condition of cod larvae with the likelihood of survival also revealed highly variable survival for larvae with low lipid reserves (Lochmann et al. 1995). While lipid depletion of sprat larvae was highest in June and July, growth rates estimated via RNA:DNA ratios as well as survival rates were also higher. Trajectory analyses on RNA:DNA ratios are a useful tool for estimating environmental selectivity. While a stable 10th percentile value of RNA:DNA most likely reflects a low-selective environment, an increase with size is the result of stronger selection against slow-growing individuals (Clemmesen et al. 2003). Accordingly, during our study period sprat larvae had a much lower 10th percentile in summer than in April or May (Voss et al. 2006), indicating a less selective food environment during summer. The evaluation of a comprehensive experimental dataset of a variety of different fish larvae and juveniles revealed that the RNA:DNA 10th percentiles can be used to estimate the worst possible biochemical condition of an individual at the edge of death (Meyer et al. 2012). Similarly, lipid levels cannot fall below a certain threshold, when structural integrity begins to collapse. However, while as a growth proxy these minimum values are directly linked to a highly critical condition, the depletion of internal energy reserves is a normal process experienced by all larvae at some point during their development. Thus, interpreting lipid condition in the light of a size-related decrease in median or 90th percentile will be of much higher relevance for estimating environmental selectivity than looking at the lower end of the distribution.

\section{Feeding and food quality}

Aside from the pivotal need of fish larvae to ingest enough suitable food to meet energetic concerns, food quality may also have a major influence on the successful recruitment of fish stocks. We therefore aimed at linking prey quality (using trophic FA markers) with larval condition and survival.

C18-FAs were important biomarkers in the lipids of all sprat larvae. Since to our knowledge this is the first study on FA composition of sprat larvae, values can only be evaluated using data on other clupeid species. 18:1(n-9) is characteristic for the food web of the Central Baltic Sea due to a generally strong contribution of the microbial loop (Peters et al. 2013). It can be synthesized de novo and generally increases with trophic level. However, 18:1(n-9) was not higher in Baltic sprat larvae than in clupeids from other 
regions (Folkvord et al. 1996, Rossi et al. 2006). The diatom marker $16: 1(n-7)$ was low with only about $1 \%$ of tFAs. The copepod Acartia spp., which represents one of the major links between primary production and sprat larvae (Dickmann et al. 2007), was found to avoid diatoms in the Central Baltic Sea (Peters et al. 2013), thus leading to a dinoflagellate and/or microbial loop based carbon flux to the sprat larvae. This is also reflected in the increased levels of polyunsaturated C18-FAs in Acartia spp. (Peters et al. 2013) and sprat larvae. The multivariate analysis, which was performed to identify month- and size-specific differences in larval FA, showed that the variation in trophic markers was primarily driven by lipid content. FA differences can therefore only be interpreted in light of the respective TL level. The FAs 16:0, 18:0, 16:1(n-9) and 18:1(n-9) were highly correlated with TL and are thus probably important components of the storage lipids. EPA and DHA, on the other hand, were negatively correlated with TL, which highlights their important role as part of structural lipids (e.g. cell membranes). In contrast, the second component of the PCA was independent of TL content and revealed differences between months, although with strong overlaps. FA patterns in April differed most strongly from all other months, specifically due to higher levels of polyunsaturated C18-FAs as well as by negative correlation with DHA.

Results of the regression analysis between DHA and TL highlight the need to account for different lipid contents when comparing relative FA values, especially typical membrane FAs such as DHA. The applied regression approach allows a comparison of organisms with different ratios of storage and structural lipids; however, an interactive effect of size and lipid content will not be resolved. The DHA:TL ratio of the larvae was significantly lower in April than in all other months, with DHA levels $<20 \%$ of tFAs at low TL reflecting the relative content of DHA in the structural lipids. In all other months, DHA reached values around $40 \%$ of tFAs. The small larvae in April fed almost exclusively on unspecified microplankton, while in all other months copepod nauplii were important food components (Dickmann et al. 2007). Pelagic copepods are generally rich in DHA (Evjemo et al. 2003, Peters et al. 2013), indicating that not only maternal but also dietary effects may have caused the lower DHA levels. The absence of nauplii in larval stomachs despite high nauplii abundance in the field may be due to prevailing environmental conditions in April, since feeding success of Baltic sprat larvae was found to be dependent on factors such as turbulence and cloudiness (Voss et al. 2008). Food quality effects might have further amplified the potentially unfavourable conditions in spring, e.g. deficiencies of DHA in neural tissues were associated with a decrease in the efficiency to capture prey at low light intensities (Bell et al. 1995). However, similar growth rates in April and May as well as high starvation resistance do not indicate reduced fitness of the DHA-deficient larvae in April. DHA is commonly discussed as one of the key components defining food quality. While there are numerous studies on its impact on fish larval growth and survival in aquaculture (Sargent et al. 1999a), evidence of its in situ relevance remains scarce. Correlation analyses on individual herring larvae revealed a significantly positive relationship for DHA content and growth, and conclusively linked this to prey availability in the field (Paulsen et al. 2014). We also observed a trend of higher DHA content with increasing growth rate. However, this is not necessarily a causal effect. RNA:DNA ratios may increase during ontogeny (Clemmesen 1994, Chícharo \& Chícharo 2008, Díaz et al. 2008, 2009, 2011, this study), while lipid contents decrease (Ehrlich 1974, Gatten et al. 1983, Díaz et al. 2008, 2009, 2011, this study). In turn, the relative portion of DHA as a major component of structural lipids increases and thus leads to the observed effect of DHA increase with size (Rossi et al. 2006, this study) or with RNA:DNA ratio.

In order to further assess the relevance of food quality (in terms of essential FAs) for sprat larvae in the Central Baltic Sea, we sampled additional sprat larvae-related components of the food web. We observed a strong enrichment in relative DHA levels of around $10 \%$ of tFAs per trophic level from seston via copepods to smaller and larger sprat larvae. Multilevel physiological mechanisms seem to be involved in the DHA accumulation in fish larvae, i.e. a selective assimilation due to high specificity of digestive enzymes (Morais \& Conceição 2009), selective incorporation into structural and neutral lipids (Mourente 2003), as well as selective retention during lipid catabolism (Koven et al. 1989). Similar accumulation of DHA through the food chain has been observed in other marine (Rossi et al. 2006) and limnic habitats (Kainz et al. 2004, Persson \& Vrede 2006), highlighting the ubiquitous occurrence of DHA at higher trophic levels in pelagic ecosystems, but also a certain robustness of fish larvae to compensate for low DHA environments. Several aquaculture studies emphasise that not only the amount of essential FAs but also their relative compositions can influence fish larval growth and survival (Copeman et al. 2002). This is attributed to the competitive interaction 
between DHA and EPA as well as EPA:ARA ratios during the enzymatic formation of structural lipid and metabolically active eicosanoids, respectively (Sargent et al. 1999a). Despite species-specific requirements, an optimal ratio of DHA:EPA:ARA was suggested to be around 10:5:1 (Sargent et al. 1999b). DHA levels were generally high in Acartia spp. and the DHA:EPA ratio always exceeded 1 , with a maximum of 1.8. In contrast, ARA levels were very low in all Baltic copepods (Peters et al. 2006, 2013) and usually never exceeded $0.5 \%$ of tFAs. Due to the lack of delta- 5 desaturase activity, marine fish are not able to convert 18:2(n-6) to ARA, hence it must be provided in the diet (Sargent et al. 1997). An imbalance in FA composition, reflected by high DHA:ARA ratios in Baltic copepods, was proposed to be one reason for reproductive disturbances in Atlantic salmon (Ahlgren et al. 2005). Furthermore, significantly reduced ARA levels were found in the polar lipids of Baltic cod when compared to oceanic stocks, and ARA content as well as the DHA:EPA ratio in the polar lipid fraction were identified as important factors influencing egg viability (Pickova et al. 1997). Due to constantly low ARA levels in all sprat larvae, an evaluation of potential negative effects on sprat larval development remains impossible until further experimental proof is obtained. However, the high stock size of sprat in the Baltic Sea suggests that there have been no substantial negative effects on the population.

\section{CONCLUSIONS}

Although lipid content does not seem to be a simple proxy for larval condition in small pelagic fish, it provides some valuable information: at the individual level it estimates the likelihood of near future starvation of the respective larva, while at the population level it reflects the size-specific environmental starvation pressure on the whole cohort of larvae (i.e. the timing and extent of first encountered imbalances between suitable prey fields and metabolic requirements during their early life history). However, the specific energy allocation during early larval development (i.e. a strong preference for somatic growth) leads to an overall decoupling of internal energy reserves and growth. Therefore, combined approaches are needed using physiological indicators for both metabolic processes - ideally on the same larvae - in order to better understand matchmismatch processes governing recruitment success. To exemplify, mechanisms acting on larvae of the same size differed between sampling months during our study. This is in accordance with the results of Voss et al. (2006), who showed that a mismatch situation with suitable prey organisms significantly influenced the survival of larger sprat larvae at the beginning of the spawning season. In contrast, the influence of biochemical prey quality on larval survival was less evident than prey size suitability. Although we detected significant differences in larval DHA concentration, an essential component of structural lipids, this had no obvious effect on growth or survival. One reason for this might be that food quality in terms of FA composition was generally high, except for a food web-specific deficiency in ARA. Overall, food quantity and the appropriate composition sensu prey size was a more important factor for recruitment success than the availability of essential FAs.

Finally, a brief comment on the use of lipids in fish larval studies: (1) sampling may be adapted to the decreasing variability with size in order to reduce analytical effort, (2) TL levels need to be interpreted only in light of larval size and size-specific variability, and accordingly FA composition only in light of TL content, and finally (3) we highlight the importance of collateral information that is often gained when using total FAs as conditional markers, e.g. on feeding and food quality.

Acknowledgements. We thank the crews and scientific parties of the RV 'Alkor', 'Heincke' and 'A.V. Humboldt' for support provided during the field phase, and especially for help with sorting hundreds of larvae. We thank P. Wencke and $\mathrm{H}$. Mempel for the excellent assistance with lipid and RNA:DNA analyses, respectively. The input of R. Voss and $\mathrm{H}$. Baumann during the early stages of data analyses is gratefully acknowledged. We also thank 3 anonymous reviewers for their helpful comments on the manuscript. The study was funded by the German Federal Ministry for Education and Research within the GLOBEC GERMANY project (03F0320C).

\section{LITERATURE CITED}

Ahlgren G, Van Nieuwerburgh L, Wänstrand I, Pedersén M, Boberg M, Snoeijs P (2005) Imbalance of fatty acids in the base of the Baltic Sea food web-a mesocosm study. Can J Fish Aquat Sci 62:2240-2253

Anderson JT (1988) A review of size dependent survival during pre-recruit stages of fishes in relation to recruitment. J Northwest Atl Fish Sci 8:55-66

Bakun A (2010) Linking climate to population variability in marine ecosystems characterized by nonsimple dynamics: conceptual templates and schematic constructs. J Mar Syst 79:361-373

Baumann H, Hinrichsen HH, Voss R, Stepputtis D, Grygiel 
W, Clausen LW, Temming A (2006) Linking growth to environmental histories in central Baltic young-of-theyear sprat, Sprattus sprattus: an approach based on otolith microstructure analysis and hydrodynamic modelling. Fish Oceanogr 15:465-476

Bell MV, Batty RS, Dick JR, Fretwell K, Navarro JC, Sargent JR (1995) Dietary deficiency of docosahexaenoic acid impairs vision at low light intensities in juvenile herring (Clupea harengus L.). Lipids 30:443-449

Buckley LJ, Caldarone EM, Clemmesen C (2008) Multi-species larval fish growth model based on temperature and fluorometrically derived RNA/DNA ratios: results from a meta-analysis. Mar Ecol Prog Ser 371:221-232

Caldarone EM, Clemmesen C, Berdalet E, Miller TJ and others (2006) Intercalibration of four spectrofluorometric protocols for measuring RNA/DNA ratios in larval and juvenile fish. Limnol Oceanogr Methods 4:153-163

- Chícharo MA, Chícharo L (2008) RNA:DNA ratio and other nucleic acid derived indices in marine ecology. Int $\mathrm{J}$ Mol Sci 9:1453-1471

> Clemmesen C (1994) The effect of food availability, age or size on the RNA/DNA ratio of individually measured herring larvae: laboratory calibration. Mar Biol 118:377-382

Clemmesen C, Bühler V, Carvalho G, Case R and others (2003) Variability in condition and growth of Atlantic cod larvae and juveniles reared in mesocosms: environmental and maternal effects. J Fish Biol 62:706-723

Coombs SH, Håkanson JL (1991) Diel variation in lipid and elemental composition of sprat (Sprattus sprattus) larvae at mixed and stratified sites in the German Bight of the North Sea. ICES CM L 49:1-11

Copeman LA, Parrish CC, Brown JA, Harel M (2002) Effects of docosahexaenoic, eicosapentaenoic, and arachidonic acids on the early growth, survival, lipid composition and pigmentation of yellowtail flounder (Limanda ferruginea): a live food enrichment experiment. Aquaculture 210:285-304

Cribari-Neto F, Zeileis A (2010) Beta regression in R. J Stat Softw 34:1-24

Cushing DH (1972) The production cycle and the number of marine fish. In: Edwards RW, Garrod DJ (eds) Conservation and productivity of natural waters. Symposia of the Zoological Society of London, No. 29. Academic Press, London, p 213-233

Cushing DH (1990) Plankton production and year-class strength in fish populations: an update of the match/ mismatch hypothesis. Adv Mar Biol 26:249-293

> Daewel U, Peck MA, Kühn W, St John MA, Alekseeva I, Schrum C (2008) Coupling ecosystem and individualbased models to simulate the influence of environmental variability on potential growth and survival of larval sprat (Sprattus sprattus L.) in the North Sea. Fish Oceanogr 17:333-351

Desvilettes C, Bourdier G, Breton JC (1997) Changes in lipid class and fatty acid composition during development in pike (Esox lucius L) eggs and larvae. Fish Physiol Biochem 16:381-393

Díaz E, Txurruka JM, Villate F (2008) Biochemical composition and condition in anchovy larvae Engraulis encrasicolus during growth. Mar Ecol Prog Ser 361:227-238

> Díaz E, Txurruka JM, Villate F (2009) Biochemical composition and somatic growth of pelagic larvae of three fish species from the Bay of Biscay. Mar Ecol Prog Ser 382: 173-183

> Díaz E, Txurruka JM, Villate F (2011) Growth maximization in early sardine larvae: a metabolic approach. Mar Biol 158:1135-1148

> Dickmann M, Möllmann C, Voss R (2007) Feeding ecology of Central Baltic sprat Sprattus sprattus larvae in relation to zooplankton dynamics: implications for survival. Mar Ecol Prog Ser 342:277-289

> Donnelly J, Torres JJ, Crabtree RE (1995) Proximate composition and nucleic acid content of premetamorphic leptocephalus larvae of the congrid eel Ariosoma balearicum. Mar Biol 123:851-858

Ehrlich KF (1974) Chemical changes during growth and starvation of herring larvae. In: Blaxter JHS (ed) Proceedings of an international symposium: the early life history of fish. Scottish Marine Biological Association, Oban. Springer, Berlin, p 301-323

Evjemo JO, Reitan KI, Olsen Y (2003) Copepods as live food organisms in the larval rearing of halibut larvae (Hippoglossus hippoglossos L.) with special emphasis on the nutritional value. Aquaculture 227:191-210

- Ferrari SLP, Cribari-Neto F (2004) Beta regression for modelling rates and proportions. J Appl Stat 31:799-815

- Ferron A, Leggett WC (1994) An appraisal of condition measures for marine fish larvae. Adv Mar Biol 30:217-303

Folch J, Lees M, Sloane-Stanley GH (1957) A simple method for isolation and purification of total lipids from animal tissues. J Biol Chem 226:497-509

Folkvord A, Haaland IM, Grahl-Nielsen O, Johannessen A (1996) Fatty acid composition of herring (Clupea harengus L.) larvae off western Norway. Sarsia 80:299-305

Gatten RR, Sargent JR, Camble JC (1983) Diet induced changes in fatty acid composition of herring larvae reared in enclosed ecosystems. J Mar Biol Assoc UK 63: $575-584$

Govoni JJ (2005) Fisheries oceanography and the ecology of early life histories of fishes: a perspective over fifty years. Sci Mar 69(Suppl 1):125-137

> Grote B, Hagen W, Lipinski MR, Verheye HM, Stenevik EK, Ekau W (2011) Lipids and fatty acids as indicators of egg condition, larval feeding and maternal effects in Cape hakes (Merluccius paradoxus and M. capensis). Mar Biol 158:1005-1017

Guisande C, Riveiro I, Sola A, Valdes L (1998) Effect of biotic and abiotic factors on the biochemical composition of wild eggs and larvae of several fish species. Mar Ecol Prog Ser 163:53-61

Håkanson JL (1989a) Condition of larval anchovy (Engraulis mordax) in the Southern California Bight, as measured through lipid analysis. Mar Biol 102:153-159

Håkanson JL (1989b) Analysis of lipid components for determining the condition of anchovy larvae, Engraulis mordax. Mar Biol 102:143-151

Håkanson JL (1993) Nutritional condition and growth rate of anchovy larvae (Engraulis mordax) in the California Current: two contrasting years. Mar Biol 115:309-316

> Håkanson JL, Coombs SH, Ré P (1994) Lipid and elemental composition of sprat (Sprattus sprattus) larvae at mixed and stratified sites in the German Bight of the North Sea. ICES J Mar Sci 51:147-154

Haslob H, Rabade-Uberos S, Saborido-Rey F (2013) Seasonal variability of fecundity and spawning dynamics of Baltic sprat. Fish Res 138:99-109

Hjort J (1914) Fluctuations in the great fisheries of northern Europe viewed in the light of biological research. Rapp Procès-Verbaux Réunions Cons Perm Int Explor Mer 20: $1-228$ 
Hjort J (1926) Fluctuations in the year classes of important food fishes. J Cons Perm Int Explor Mer 1:5-38

Kainz M, Arts MT, Mazumder A (2004) Essential fatty acids in the planktonic food web and their ecological role for higher trophic levels. Limnol Oceanogr 49:1784-1793

Kamler E (2008) Resource allocation in yolk-feeding fish. Rev Fish Biol Fish 18:143-200

- Kattner G, Fricke HSG (1986) Simple gas-liquid chromatography method for simultaneous determination of fatty acids and alcohols in wax esters of marine organisms. J Chromatogr A 361:263-268

Köster FW, Hinrichsen HH, Schnack D, St. John MA and others (2003) Recruitment of Baltic cod and sprat stocks: identification of critical life stages and incorporation of environmental variability into stock-recruitment relationships. Sci Mar 67:129-154

Koven WM, Kissil GWm, Tandler A (1989) Lipid and $n$-3 requirement of Sparus aurata larvae during starvation and feeding. Aquaculture 79:185-191

Leggett WC, Deblois E (1994) Recruitment in marine fishes: Is it regulated by starvation and predation in the egg and larval stages? Neth J Sea Res 32:119-134

> Lochmann SE, Maillet GL, Frank KT, Taggart CT (1995) Lipid class composition as a measure of nutritional condition in individual larval Atlantic cod (Gadus morhua). Can J Fish Aquat Sci 52:1294-1306

> Martell DJ, Kieffer JD, Trippel EA (2005) Effects of temperature during early life history on embryonic and larval development and growth in haddock. J Fish Biol 66: 1558-1575

Meyer S, Caldarone EM, Chícharo MA, Clemmesen C and others (2012) On the edge of death: rates of decline and lower thresholds of biochemical condition in fooddeprived fish larvae and juveniles. J Mar Syst 93:11-24

Morais S, Conceição LE (2009) A new method for the study of essential fatty acid requirements in fish larvae. Br J Nutr 101:1564-1568

Mourente G (2003) Accumulation of DHA (docosahexaenoic acid; 22:6n-3) in larval and juvenile fish brain. In: Browman HI, Skiftesvik AB (eds) The big fish bang: Proceedings of the 26th annual larval fish conference. Institute of Marine Research, Bergen, p 239-248

> Muggeo VMR (2003) Estimating regression models with unknown breakpoints. Stat Med 22:3055-3071

Paulsen M, Clemmesen C, Malzahn AM (2014) Essential fatty acid (docosahexaenoic acid, DHA) availability affects growth of larval herring in the field. Mar Biol 161:239-244

> Persson J, Vrede T (2006) Polyunsaturated fatty acids in zooplankton: variation due to taxonomy and trophic position. Freshw Biol 51:887-900

> Petereit C, Haslob H, Kraus G, Clemmesen C (2008) The influence of temperature on the development of Baltic Sea sprat (Sprattus sprattus) eggs and yolk sac larvae. Mar Biol 154:295-306

> Peters J, Renz J, van Beusekom J, Boersma M, Hagen W (2006) Trophodynamics and seasonal cycle of the copepod Pseudocalanus acuspes in the Central Baltic Sea (Bornholm Basin): evidence from lipid composition. Mar Biol 149:1417-1429

> Peters J, Dutz J, Hagen W (2013) Trophodynamics and life-

Editorial responsibility: Edward Durbin,

Narragansett, Rhode Island, USA cycle strategies of the copepods Temora longicornis and Acartia longiremis in the Central Baltic Sea. J Plankton Res 35:595-609

Pickova J, Dutta PC, Larsson PO, Kiessling A (1997) Early embryonic cleavage pattern, hatching success, and egglipid fatty acid composition: comparison between two cod (Gadus morhua) stocks. Can J Fish Aquat Sci 54: 2410-2416

Rossi S, Sabatés A, Latasa M, Reyes E (2006) Lipid biomarkers and trophic linkages between phytoplankton, zooplankton and anchovy (Engraulis encrasicolus) larvae in the NW Mediterranean. J Plankton Res 28:551-562

Sargent J, McEvoy L, Bell JG (1997) Requirements, presentation and sources of polyunsaturated fatty acids in marine fish larval feeds. Aquaculture 155:117-127

Sargent J, McEvoy L, Estevez A, Bell G, Bell M, Henderson J, Tocher D (1999a) Lipid nutrition of marine fish during early development: current status and future directions. Aquaculture 179:217-229

Sargent J, Bell G, McEvoy L, Tocher D, Estevez A (1999b) Recent developments in the essential fatty acid nutrition of fish. Aquaculture 177:191-199

Schneider CA, Rasband WS, Eliceiri KW (2012) NIH Image to ImageJ: 25 years of image analysis. Nat Methods 9: 671-675

> Shepherd JG, Cushing DH (1980) A mechanism for densitydependent survival of larval fish as the basis of a stockrecruitment relationship. ICES J Mar Sci 39:160-167

Suthers IM, Fraser A, Frank KT (1992) Comparison of lipid, otolith and morphometric condition indices of pelagic juvenile cod Gadus morhua from the Canadian Atlantic. Mar Ecol Prog Ser 84:31-40

> Tocher DR, Fraser AJ, Sargent JR, Gamble JC (1985) Lipid class composition during embryonic and early larval development in Atlantic herring (Clupea harengus, L.). Lipids 20:84-89

> Voss R, Clemmesen C, Baumann H, Hinrichsen HH (2006) Baltic sprat larvae: coupling food availability, larval condition and survival. Mar Ecol Prog Ser 308:243-254

> Voss R, Schmidt JO, Schnack D (2007) Vertical distribution of Baltic sprat larvae: changes in patterns of diel migration? ICES J Mar Sci 64:956-962

Voss R, Dickmann M, Hinrichsen HH, Floeter J (2008) Environmental factors influencing larval sprat Sprattus sprattus feeding during spawning time in the Baltic Sea. Fish Oceanogr, 17:219-230

- Voss R, Hinrichsen HH, Stepputtis D, Bernreuther M, Huwer B, Neumann V, Schmidt JO (2011) Egg mortality: predation and hydrography in the central Baltic. ICES J Mar Sci 68:1379-1390

Ware DM (1975) Relation between egg size, growth, and natural mortality of larval fish. J Fish Board Can 32: 2503-2512

Wood SN (2001) Minimizing model fitting objectives that contain spurious local minima by bootstrap restarting. Biometrics 57:240-244

Zenitani H (1999) Size-specific changes in amount of lipid and daily growth rate of early larval sardine, Sardinops melanostictus, in the main Kuroshio Current and its offshore waters off eastern Japan. Mar Biol 134:645-652

Submitted: May 5, 2014; Accepted: March 20, 2015

Proofs received from author(s): June 23, 2015 